\title{
SEM ANALYSIS OF THE ACID-ETCHED ENAMEL PATTERNS PROMOTED BY ACIDIC MONOMERS AND PHOSPHORIC ACIDS
}

\author{
AVALIACÃO EM MEV DO PADRÃO DE CONDICIONAMENTO DO ESMALTE DENTAL \\ PROMOVIDO POR MONÔMEROS ÁCIDOS E O ÁCIDO FOSFÓRICO
}

\author{
Mirela Sanae SHINOHARA ${ }^{1}$, Marcelo Tavares de OLIVEIRA $^{1}$, Vinícius Di HIPÓLITO ${ }^{1}$, \\ Marcelo GIANNINI ${ }^{2}$, Mario Fernando de GOES ${ }^{3}$
}

\begin{abstract}
1- DDS, MSc, Graduate student (Doctor degree), Department of Restorative Dentistry, Piracicaba School of Dentistry, Campinas State University, Piracicaba, SP, Brazil.

2- DDS, MSc, PhD, Associate Professor, Department of Restorative Dentistry, Piracicaba School of Dentistry, Campinas State University, Piracicaba, SP, Brazil.

3- DDS, MSc, PhD, Full Professor, Department of Restorative Dentistry, Piracicaba School of Dentistry, Campinas State University, Piracicaba, SP, Brazil.
\end{abstract}

Corresponding address: Prof. Dr. Mario Fernando De Goes - Dental Materials Section - Department of Restorative Dentistry Piracicaba School of Dentistry - State University of Campinas - Av. Limeira, 901 - Piracicaba/SP - Brazil - Phone: +55 1921065346 Fax: +55 1921065218 - e-mail: degoes@fop.unicamp.br

Received: May 25, 2006 - Modification: July 18, 2006 - Accepted: September 06, 2006

\begin{abstract}
$O$ bjective: Although self-etching bonding systems (SES) are indicated to prepare dental enamel for bonding, concerns have been expressed regarding their effectiveness. The aim of this study was to analyze the etching pattern (EP) of nine SES in comparison with 35\% and 34\% phosphoric acid etchants (FA) on intact (IN) and ground (GR) enamel surface. Materials and Methods: Twenty-two human third molars were sectioned in mesial-distal and buccal-lingual directions, and four dental fragments were obtained from each tooth. Half of the fragments were ground using 600-grit SiC paper and the other half remained intact. The fragments were randomly assigned into 22 groups, according to the texture of enamel surface (IN and GR) and the technique to etch the enamel (34\% FA, 35\% FA, AdheSE primer; Brush \& Bond; Clearfil Protect Bond primer; iBond; One-up Bond F; OptiBond Solo Plus primer; Tyrian SPE primer; Unifil Bond primer and Xeno III). Conditioners were applied to IN and GR enamel surfaces, according to the manufacturer's instructions. Specimens etched with phosphoric acids were washed with water, while the surfaces treated with SES were submitted to alternate rinsing with alcohol and acetone. The specimens were dried, sputter-coated and examined under a scanning electron microscope. Results: For both IN and GR enamel surfaces, the EP of 34 and 35\% FA was deeper and more homogeneous in comparison to EP of SES, except for Tyrian SPE. The acidic monomer action of self-etching systems was more effective on GR enamel. Conclusion: Most of the SES are less aggressive than phosphoric acid etchants and their etching effects were reduced on intact enamel surfaces. Uniterms: Dental acid etching; Dental enamel; Electron microscopy.
\end{abstract}

\begin{abstract}
RESUMO
O

bjetivo: Apesar dos sistemas adesivos autocondicionantes (SAA) serem indicados para aplicação no esmalte dental, preocupação tem sido relatada com relação a sua efetividade. O objetivo deste estudo foi avaliar o padrão de condicionamento ácido (PCA) promovido por nove SAA e comparar ao PCA produzido pelo ácido fosfórico (35\% e 34\% - AF) no esmalte intacto (EI) ou abrasionado (EA). Materiais e Métodos: Vinte e dois terceiros molares humanos foram seccionados nos sentidos mésio-distal e vestíbulo-lingual, e quatro fragmentos dentais foram obtidos a partir de cada dente. Metade dos fragmentos tiveram o esmalte abrasionado com lixas de SiC (600) e a outra metade permaneceu intacta. Os fragmentos foram divididos em 22 grupos, de acordo com a textura da superfície do esmalte (EI e EA) e a técnica de condicionar o esmalte (AF $34 \%$, AF 35\%, AdheSE primer; Brush \& Bond; Clearfil Protect Bond primer; iBond; One-up Bond F; OptiBond Solo Plus primer; Tyrian SPE primer; Unifil Bond primer e Xeno III). Os agentes condicionadores foram aplicados nos EI e EA, de acordo com as instruções dos fabricantes. Espécimes tratados com AF foram lavados com água, enquanto os dentes tratados com SAA foram tratados com banhos alternados de álcool e acetona. Os espécimes foram secos, metalizados e observados em microscopia eletrônica de varredura. Resultados: Em ambas as superfícies (EI e EA), o PCA dos AF (34 e 35\%) foi mais profundo e homogêneo, quando comparados ao PCA produzido pelos SAA, exceto para o adesivo Tyrian SPE. A ação dos monômeros ácidos dos SAA foi mais efetiva no EA. Conclusão: A maioria dos SAA é menos agressiva que o ácido fosfórico e seus efeitos condicionadores são reduzidos em superfícies de EI.
\end{abstract}

Unitermos: Ataque ácido dentário; Esmalte dentário; Microscopia eletrônica. 


\section{INTRODUCTION}

Buonocore $^{2}$ (1955) reported that bonding to enamel surface could be increased by conditioning the surface with $85 \%$ phosphoric acid for 30 seconds. Since this study, acid etching has been intensely used to prepare the tooth substrate for bonding. A proper enamel conditioning produces a selective dissolution, resulting in one of three etching patterns. Phosphoric acid etching removes approximately $10 \mu \mathrm{m}$ of the enamel surface, creating a porous layer and increasing the surface energy and wettability ${ }^{25,27}$.

Although the adhesion to enamel produced by phosphoric acid etching has been considered stronger and more durable, self-etching adhesives are alternative methods to prepare the tooth for restorative procedures. These adhesive systems have simplified clinical use because they do not require separated phosphoric acid etching, water rinsing or superficial moist controlling steps. However, studies evaluating self-etching adhesives are in disagreement regarding the efficacy of conditioning and monomer infiltration on enamel ${ }^{10,13,17,18,20}$.

Morphological analyses of enamel surface treated with self-etching primers have shown not very demineralized surfaces and other areas that were predominantly unetched $^{14,16,29}$. In an attempt to improve the bonding of self-etching systems to enamel, surface pre-treatments, increase in acidic monomer concentration, increase of etching time as well as different application methods have been recommended, 7,10,12,16,21.

The purpose of this in vitro study was to compare the effects of self-etching adhesive systems and conventional phosphoric acid etchants on the morphology and the acid etching pattern of intact and ground enamel. The hypothesis was that the self-etching systems do not etch the ground and intact enamel surfaces such as phosphoric acid gels.

\section{MATERIALS AND METHODS}

Twenty-two extracted, caries-free erupted human third molars were used in this study according to protocols approved by the institutional review board of the Piracicaba School of Dentistry - University of Campinas (069/2003). Teeth were obtained from patients from 19 to 25 years old and stored in saline with $0.1 \%$ thymol for no longer than 3 months.

Tooth roots were severed and the crowns were longitudinally sectioned (mesio-distally and buccal-lingually directions) into four quarters, using a diamond blade (Isomet, Buehler Ltd., Lake Bluff, IL, USA) under water cooling. Eighty-eight dental fragments were obtained. The buccal or the lingual flat enamel surface of each fragment was chosen and selected for conditioning treatments and bonding procedures. No proximal surface was used in this study. All specimens were randomly assigned to twenty-two groups $(n=4)$, according to surface treatment of enamel (ground and unground) and type of acid etching (self-etching and phosphoric acid). The dental fragments from the ground surface groups had their enamel surface abraded with a \#600grit $\mathrm{SiC}$ paper on a polishing machine (APL-4, Arotec S.A. Ind. Com., Cotia, SP, Brazil) under water cooling for 15 seconds.

Experimental groups comprised enamel treatments with two phosphoric acid concentrations: 35\% (3M ESPE, St. Paul, MN, USA) and 34\% (Dentsply Caulk, Milford, DE, USA); five acidic primers of two-step self-priming systems (AdheSE - Ivoclar Vivadent, Schaan, Liechtenstein; Clearfil Protect Bond - Kuraray Medical Inc., Kurashiki, Okayama, Japan; Optibond Solo Plus Self-Etch - Kerr Corp., Orange, CA, USA; Unifil Bond - GC Corp., Itabashi-ku, Tokyo, Japan; Tyrian SPE - Bisco Inc., Schaumburg, IL, USA) and four one-step self-etching adhesives (Brush \& Bond - Parkell Inc., Edgewood, NY, USA; i-Bond- Heraeus Kulzer, Hanau, Germany; One-Up Bond F - Tokuyama Dental Corp., Taitouku, Tokyo, Japan, Xeno III - Dentsply DeTrey, Konstanz, Germany). Phosphoric acids were applied to the ground and intact enamel surfaces and left undisturbed for 15 seconds, rinsed with water spray for 30 seconds and dried for 30 seconds. Self-etching primer adhesives were applied according to the directions recommended by manufacturers. The composition, manufacturers and directions of selfadhesive systems are described in Table 1.

Specimens treated with self-etching primers were thoroughly rinsed with acetone and ethanol solutions in order to dissolve and remove the self-etching primer and adhesive resins ${ }^{5}$. All specimens were dried, dehydrated in a desiccator for 12 hours and treated enamel surfaces were sputter-coated with gold/palladium in a vacuum evaporator (SCD 050, Balzers, Schaan, Liechtenstein). The entire surface of treated enamel was examined under a scanning electron microscope (JSM 5600LV, JEOL, Tokyo, Japan), however, only photomicrographs of representative surface areas were taken at 10,000X magnification.

\section{RESULTS}

Phosphoric acid etchants changed the enamel morphology for both intact and ground surfaces (Figures 1 and 2). Dissolution of prism cores and boundary regions can be observed, however, the conditioning of enamel surface was not uniform along the unground surfaces (Figure 2b). No distinct morphological differences between the phosphoric acid concentrations (34\% and 35\%) were observed on the etched enamel surfaces.

Figures 3 to 11 represent the morphology of enamel surface treated with self-etching systems. The etching patterns ranged from mild demineralization to an aspect of surfaces etched with phosphoric acid. Tyrian SPE selfetching primer produced dissolution of enamel surface, exposing enamel crystallites, which resulted in an etching pattern similar to that created by phosphoric acid etchants (Figure 9). Mild demineralization was promoted by Brush \& Bond, One-Up Bond F, Clearfil Protect Bond and Unifil Bond self-etching adhesives (Figures 4, 5, 7 and 10), whereas AdheSE, iBond, Optibond Solo Plus and Xeno III (Figures 
3, 6, 8 and 11) resulted in moderate mineral dissolution. Ground enamel allowed the self-etching primers to condition the subsurface enamel, exposing crystallites when the etching pattern was considered at least moderate (Figures 3a, 6a, 8a, 9a, 11a).

\section{DISCUSSION}

Self-etching systems are aqueous mixtures of polymerizable acidic monomers and methacrylate components. Acidic monomers have been developed containing esters from phosphoric acid, carboxylic acid or derivatives ${ }^{12,14,18,21}$. Their etching efficacy depends on acidic monomer, $\mathrm{pH}$ of adhesive solution, etching time and application method ${ }^{3,16,18}$. They are responsible for etching the dental substrates, whereas methacrylate components, such as HEMA, are available for monomer infiltration and polymerization of the bonding agent $t^{8,10,12,13}$. As the application of self-etching adhesives comprises simplified bonding procedures, there have been concerns regarding the longevity of bonding, according to some in vitro and in

TABLE 1- Composition, lot number and application mode of self-etching systems

\begin{tabular}{|c|c|c|c|}
\hline $\begin{array}{l}\text { Self-etching } \\
\text { adhesive }\end{array}$ & Composition (pH value) & Lot number & Procedures \\
\hline AdheSE & $\begin{array}{l}\text { primer: dimethacrylate, phosphonic acid acrylate, initiators, } \\
\text { stabilizers and water (1.7). }\end{array}$ & F53302 & a, b (15 s), c (15 s), d \\
\hline Brush \& Bond & $\begin{array}{l}\text { MMA (methyl methacrylate), 4META } \\
\text { (4-methacryloxyethyltrimellitic acid anhydride, } \\
\text { Tris (2-hydroxyethyl), THIT (isocyanurat-triacylate), } \\
\text { HEMA, acetone (2.5). }\end{array}$ & $\begin{array}{l}\text { GR1 } \\
\text { GS1 }\end{array}$ & $a, b, c(20 s), d(10 s)$ \\
\hline $\begin{array}{l}\text { Clearfil Protect } \\
\text { Bond }\end{array}$ & $\begin{array}{l}\text { primer: MDP (10-methacryloyloxydecyl dihydrogen } \\
\text { phosphate), MDPB (12-methacryloyloxydecylpyridinium } \\
\text { bromide), HEMA, hydrophilic dimethacrylate, water (2.5). }\end{array}$ & 51111 & a, b (20s), d \\
\hline iBond & $\begin{array}{l}\text { acetone/water, UDMA (urethane dimethacrylate), } \\
\text { 4-META, glutaraldehyde (1.6). }\end{array}$ & 010024 & $a, b$ (3 coats), d \\
\hline $\begin{array}{l}\text { One-Up } \\
\text { Bond F }\end{array}$ & $\begin{array}{l}\text { liquid a: methacryloyloxyalkyl acid phosphate, } \\
\text { multifunctional methacrylic monomer. } \\
\text { liquid b: coumarin dye, HEMA, fluoroaluminosilicate glass, } \\
\text { photoinitiator aryl borate catalyst, water (2.6). }\end{array}$ & $a-040$ & $b-537 a, e, f, c(20 s)$ \\
\hline $\begin{array}{l}\text { Optibond } \\
\text { Solo Plus }\end{array}$ & $\begin{array}{l}\text { primer: dimethacrylate resins, HEMA, stabilizers, } \\
\text { ethanol, water (1.5). }\end{array}$ & 203A53 & a, b (15 s), d (3 s) \\
\hline Tyrian SPE & $\begin{array}{l}\text { primer: 2-Acrylamido-2-methyl propanesulfonic acid, Bis } \\
\text { (2-(methacryloyloxy) ethyl) phosphate, ethanol (0.5). }\end{array}$ & 0200002694 & a, b (2 coats), d (5s) \\
\hline Unifil Bond & $\begin{array}{l}\text { primer: 4-MET (4-methacryloxyethyl trimellitic acid), } \\
\text { HEMA, ethanol, water (2.2). }\end{array}$ & 0302251 & $a, b, c(20 s), d(5 s)$ \\
\hline Xeno III & $\begin{array}{l}\text { liquid a: HEMA, BHT, silicon dioxide, water, ethanol. } \\
\text { liquid b: Phosphoric acid functionalised polymethacrylate } \\
\text { resins, di- and polyfunctionalised methacrylate resins, } \\
\text { BHT, CQ, 4-dimethylamino-ethyl-benzoate (1.4). }\end{array}$ & 0304001675 & $a, e(5 s), f, c(20 s), d$ \\
\hline
\end{tabular}

Procedures - a: air-dry; b: apply primer; c: leave undisturbed; d: gently air-dry; e: mix liquid a and b; f: apply mixture. Abbreviations - BHT: Butylated hydroxyl toluene; CQ: camphorquinone; HEMA: 2-hydroxyethyl methacrylate. 
vivo results ${ }^{4,15,24}$.

Studies have shown that most of the self-etching adhesives did not etch enamel as deeply as the phosphoric acid etchants did and the shallow etching pattern could compromise the bonding to enamel ${ }^{6,10,15,21}$. Pashley and Tay ${ }^{18}$ (2001) reported that the efficacy of self-etching primers in intact enamel does not depend solely upon their etching aggressiveness, but also on monomeric composition of each material. It is also possible that the low enamel bond strengths might be caused by the high amount of unpolymerized acidic monomers remaining after curing ${ }^{13}$. Thus, no correlation among degree of primer aggressiveness, enamel etching pattern and bond strength to unground enamel has been reported for self-etching adhesives $^{9,23}$.

The etching effect of phosphoric acid etchants was similar to that previously described by Retief ${ }^{25}$ (1973) and Silverstone, et al. ${ }^{27}$ (1975). The prism cores and boundaries were etched by 34\% and 35\% phosphoric acids, causing dissolution of both inter and intraprismatic areas. The predominant etching pattern was type 2 , which has the peripheral region of prisms removed and prism cores relatively unaffected (Figures 1a and 2a).

The unground enamel treated with phosphoric acids also showed formation of a porous surface, exhibiting the exposed enamel crystallites along the entire surface (Figures. $1 \mathrm{~b}$ and $2 \mathrm{~b})$. However, the etching pattern was not uniform throughout the surfaces. Some areas showed little etching effects, whereas other areas exhibited extensive demineralization. Figure $2 \mathrm{~b}$ shows the remnants of aprismatic or prismless layer that was partially dissolved by phosphoric acid etching. In this current study, as enamel surfaces were obtained from third molars, it was possible that the treated outer enamel layer would be prismless ${ }^{22}$.

Although phosphoric acid etchants present $\mathrm{pH}$ below $1^{19}$, unground enamel surfaces were not totally attacked or conditioned by acid etching. The $\mathrm{pH}$ values of all selfetching systems tested were higher than that for phosphoric acid. In general, the demineralization effects of these systems were proportional to the acidity of the acidic primers or selfetching adhesive solutions. The self-etching primers were less aggressive than phosphoric acid etchants and the conditioning effects were also reduced in unground enamel surfaces, except for Tyrian SPE self-etching primer. This result is in agreement with other studies that demonstrated that self-etching adhesives do not form a proper and defined acid etching pattern in intact surfaces ${ }^{5,10,14,21,23}$. SEM observations indicated that only shallow pits were produced after some self-etching treatments in intact enamel (Figures 6b, 8b, 10b and 11b).

The removal of superficial, aprismatic layer by wetgrinding with 600-grit $\mathrm{SiC}$ paper improved the etching effects. The morphological structure and composition of the intact peripheral surface of enamel is different from that of the middle enamel layer ${ }^{22}$. These differences can be favorable for etching effects in subsurface enamel. For Tyrian SPE primer, the etching pattern on the ground surface was similar to phosphoric acid-etched enamel (Figure 9a). However, the aggressiveness of the acidic primer has not ensured that consistent bonding may be established ${ }^{13,18,26}$.

Examination of ground enamel surfaces treated with Brush \& Bond, Clearfil Protect Bond, One-Up Bond F and Unifil Bond self-etching systems (Figures 4a, 5a, 7a and 10a) revealed that the surfaces were predominantly unetched. AdheSE, iBond, Optibond Bond Solo Plus and Xeno III self-etching systems resulted in moderate and particular etching pattern that comprised demineralization of the surface with exposure of the enamel crystallites (Figures 3a, 6a, 8a and 11a).

The self-etching primer mechanism of bonding to enamel is based on nanoretentive interlocking between crystallites and adhesive resin ${ }^{9,26}$. These morphological features of the resin-enamel bonds are different from that formed with the etch\&rinse adhesive systems $s^{9,11,23,26}$. This thin hybridized complex of resin in enamel produced by self-etching without the usual micrometer-size resin tags can be responsible for lower bond strength and questionable effectiveness on enamel surfaces ${ }^{1,28,30}$. Based on scientific evidence, some authors have recommended the instrumentation of enamel before bonding, in attempt to increase the bond strength $^{6,14,21,23}$. Thus, resin bond strength achieved with self-etching systems are sometimes comparable to those achieved with phosphoric acid, despite the differences between enamel etching patterns $s^{8,12,13,14,20}$. However, the controversy about the effectiveness still remain, since other studies did not show the same results of bond strength $^{1,6,11,28,30}$.

Regarding acid etching technique, it is well established that phosphoric acid provides good adhesion to both ground and unground enamel ${ }^{2,19,25,27}$. Because the action of self-etching primers resulted in much less demineralization of intact enamel surfaces, enamel abrasion during cavity preparation can favor the formation of a defined etching pattern. Since in clinical situations the enamel is usually prepared with dental drills prior to application of the adhesive system, the concerns about effectiveness of self-etching adhesives can be reduced. However, the effects of selfetching adhesive systems must be further studied to verify the durability of bonding to enamel.

\section{CONCLUSION}

The self-etching systems did not etch the ground and intact enamel surfaces as phosphoric acid etchants did. Their conditioning effects were reduced on intact enamel surfaces, except for Tyrian SPE system. The acid-etched enamel patterns formed by acidic monomers were observed only on ground surfaces.

\section{ACKNOWLEDGEMENT}

This study was supported by grants 03/08090-7 from FAPESP and by grants from Capes, Brazil. 


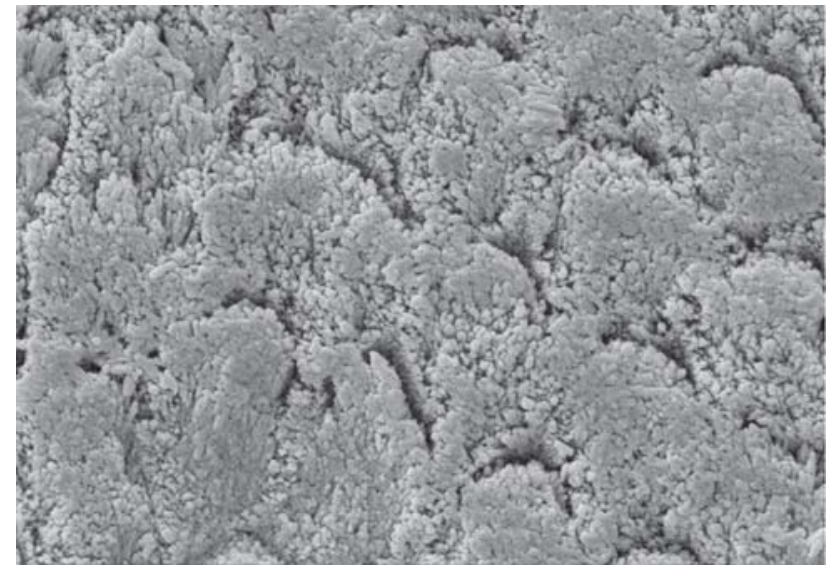

a

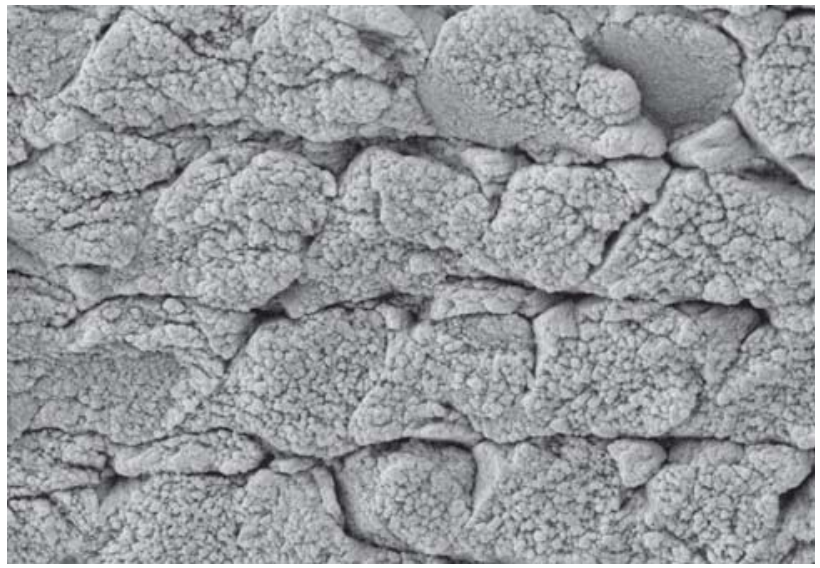

b

FIGURE 1- SEMs of ground (1a) and intact (1b) enamel surfaces etched with $34 \%$ phosphoric acid. Dissolution of prism core and boundaries can be observed $(x 10,000)$

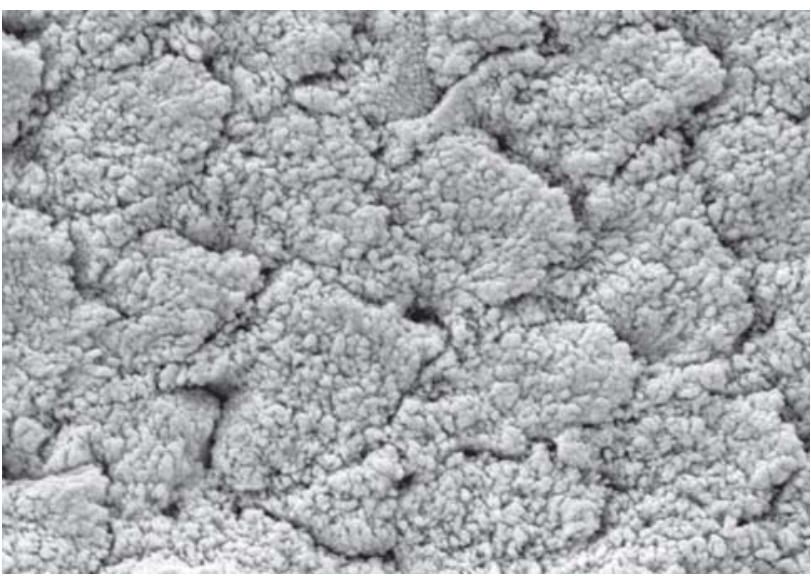

a

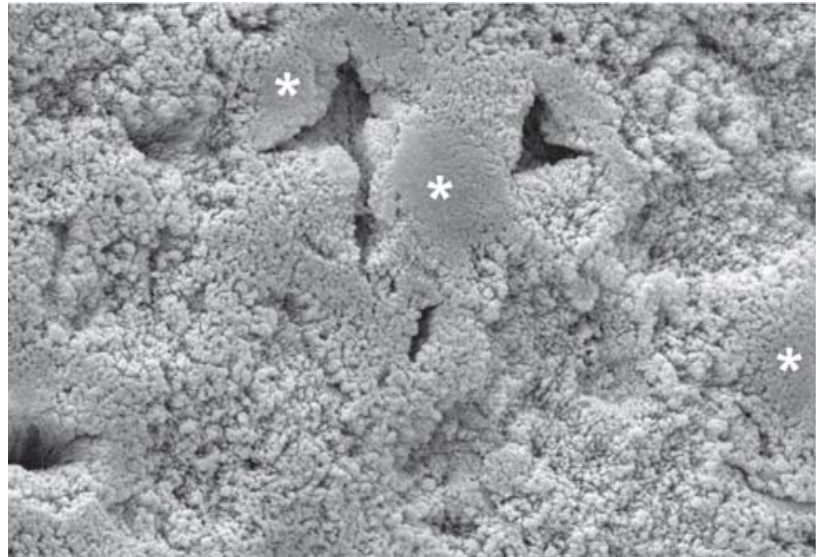

b

FIGURE 2- SEMs of ground (2a) and intact (2b) enamel surfaces etched with $35 \%$ phosphoric acid. Dissolution of prism core and boundaries can be observed $(2 \mathrm{a})$ and a non-uniform etching with aprismatic layer remnants $\left(^{*}\right)$ in intact surfaces $(2 \mathrm{~b})$ $(x 10,000)$

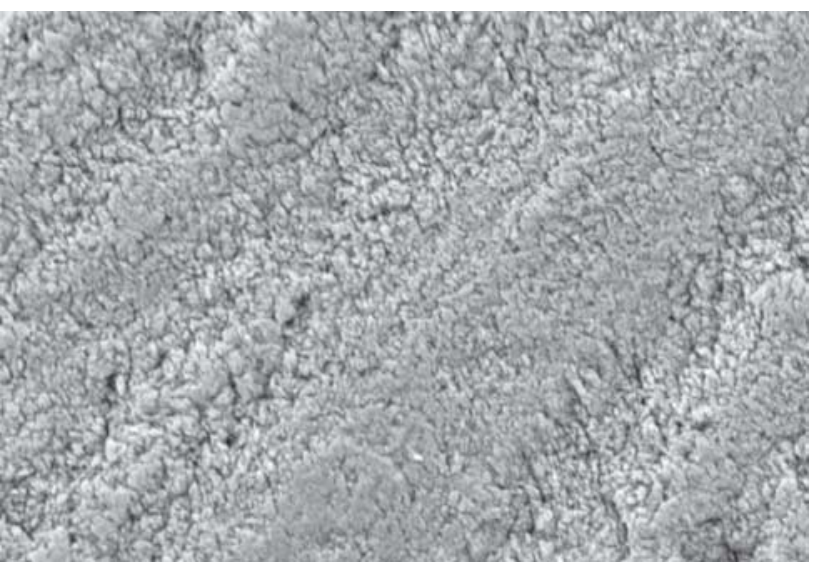

a

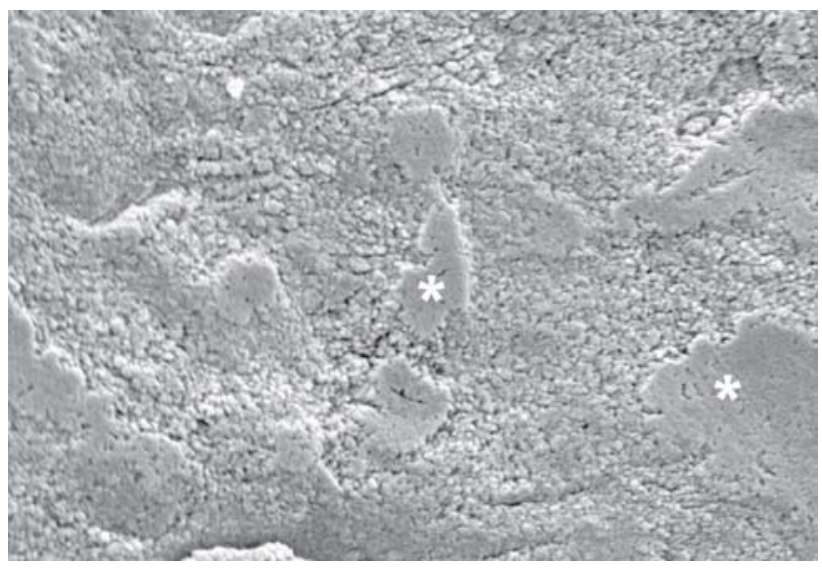

b

FIGURE 3- SEMs of ground (3a) and intact (3b) enamel surfaces treated with AdheSE self-etching primer. Exposed enamel crystallites were noted in ground surfaces (3a), whereas, the aprismatic layer remnants () were present in intact surfaces (3b) $(\times 10,000)$ 


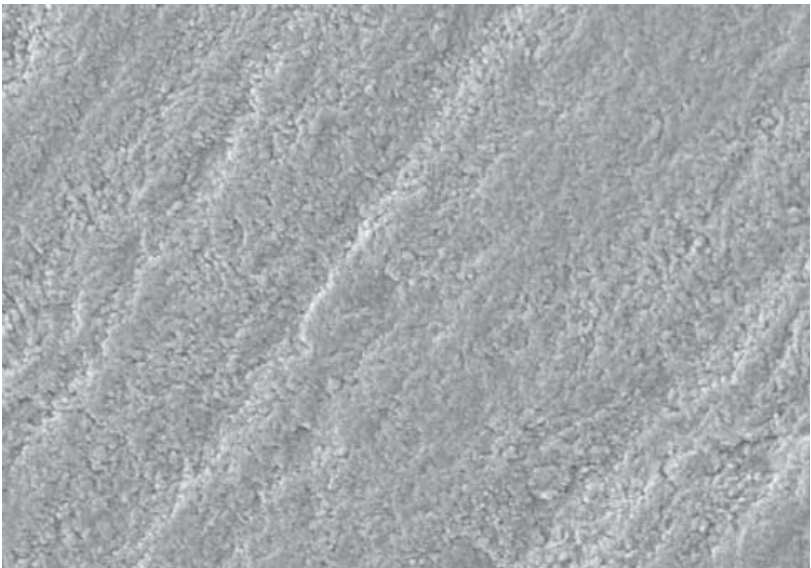

a

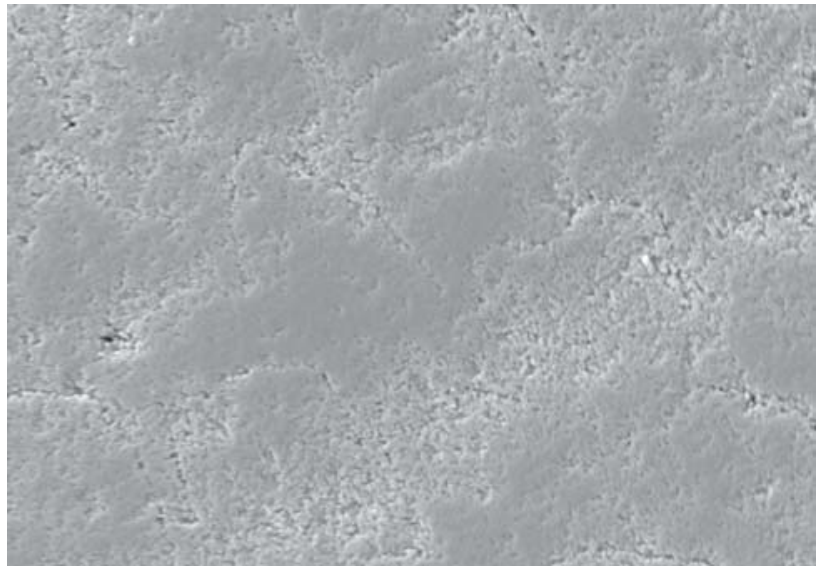

b

FIGURE 4- SEMs of ground (4a) and intact (4b) enamel surfaces treated with Brush \& Bond self-etching adhesive. Adhesive treatment resulted in a mild etching pattern $(x 10,000)$

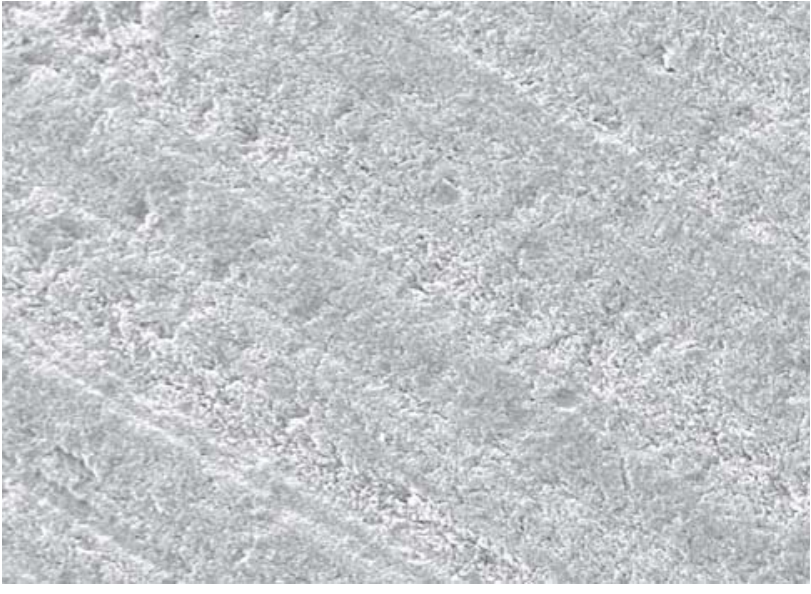

a

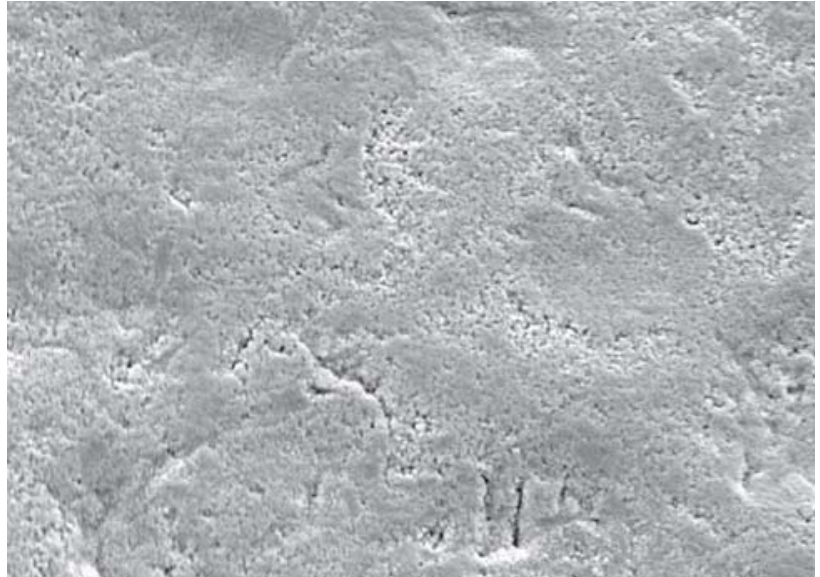

b

FIGURE 5- SEMs of ground (5a) and intact (5b) enamel surfaces treated with Clearfil Protect Bond self-etching primer. Exposed enamel crystallites were observed in scratches left by the SiC abrasive paper (5a). Superficial layer remnants were observed in intact surfaces $(5 b)(x 10,000)$

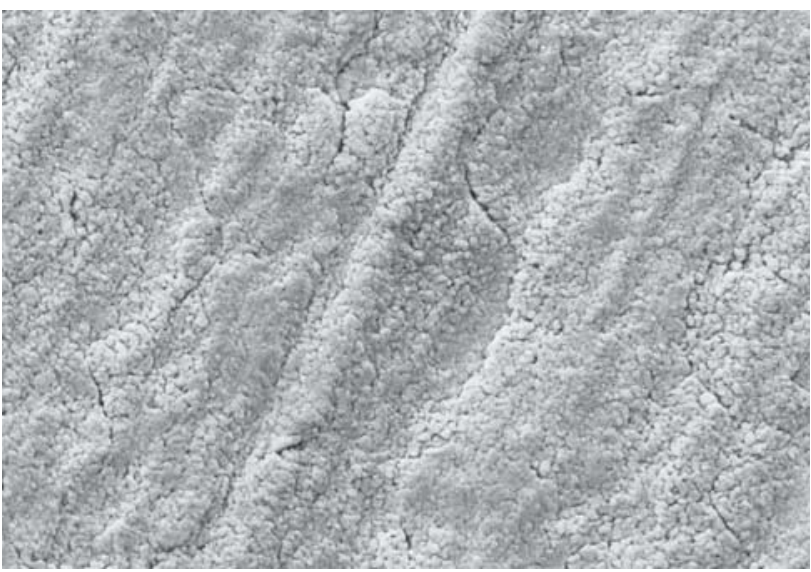

a

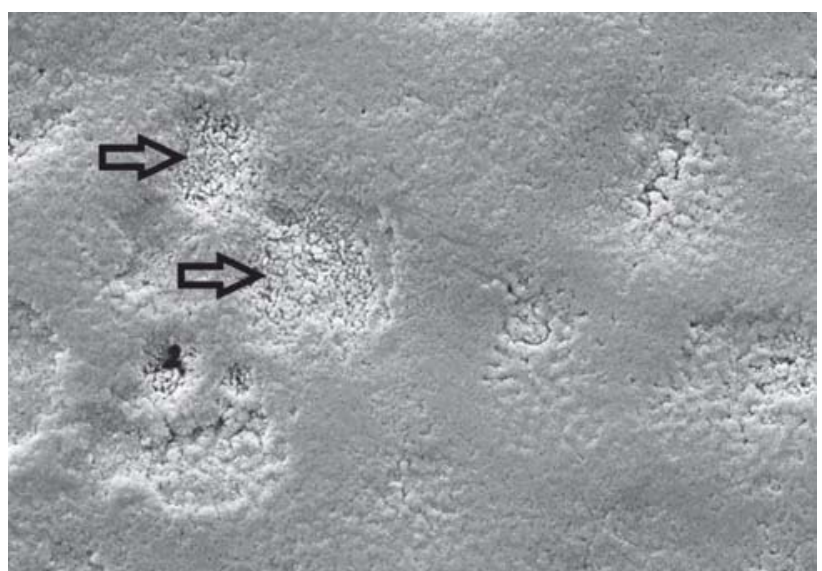

b

FIGURE 6- SEMs of ground (6a) and intact (6b) enamel surfaces treated with i-Bond self-etching adhesive. Enamel crystallites were exposed by adhesive application in grounded surfaces (6a) and shallow pits (arrows) were noted along the intact surfaces $(6 b)(x 10,000)$ 


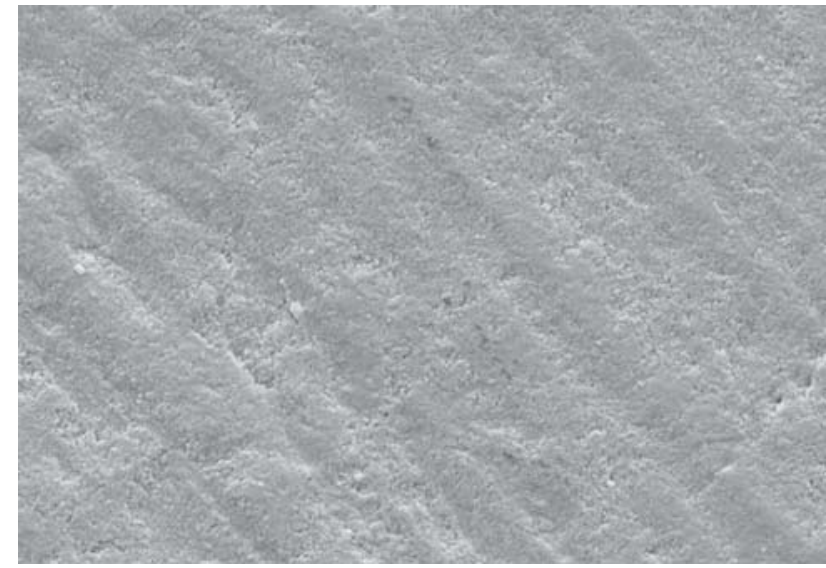

a

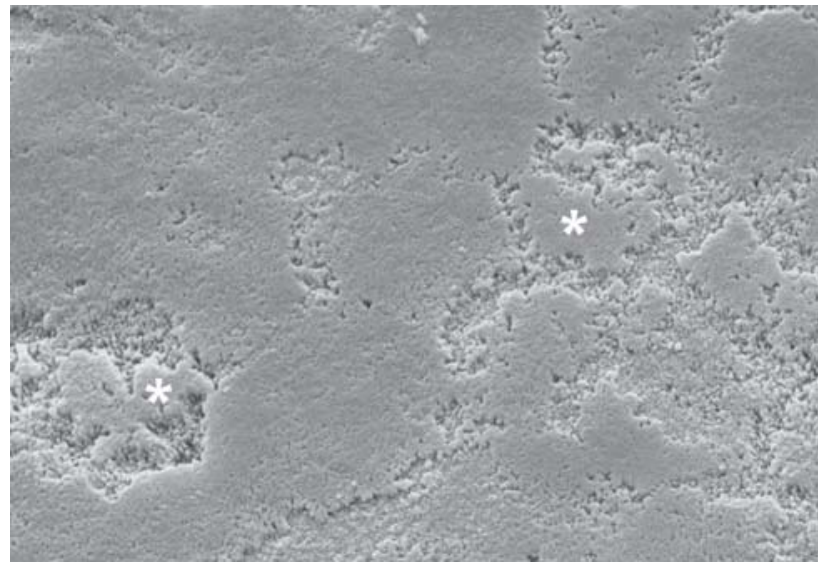

b

FIGURE 7- SEMs of ground (7a) and intact (7b) enamel surfaces treated with One-Up Bond F self-etching adhesive. Adhesive treatment resulted in a mild etching pattern. The aprismatic layer $(*)$ remained after treatment $(7 b)(\times 10,000)$

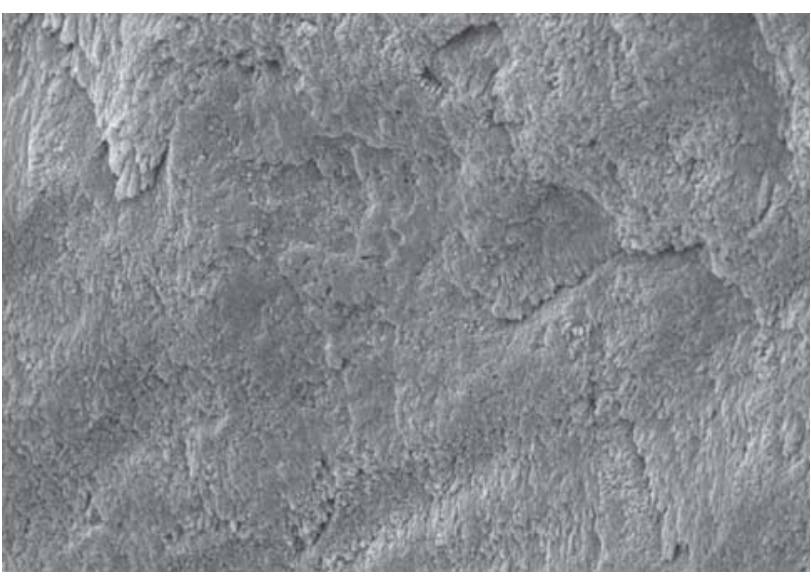

a

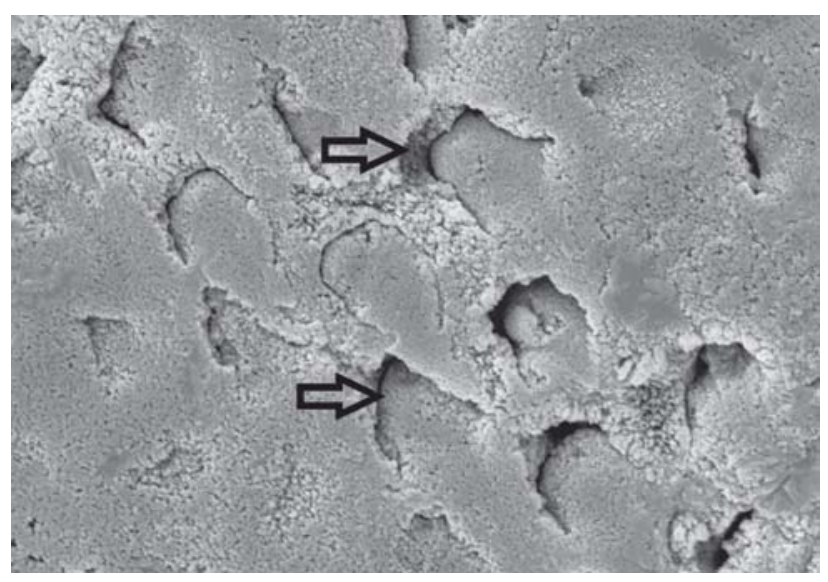

b

FIGURE 8- SEMs of ground (8a) and intact (8b) enamel surfaces treated with Optibond Bond Solo Plus self-etching primer. Moderate etching pattern was obtained after adhesive treatment (8a). Some areas showed etching effects at enamel prisms (arrows) (8b) (x10,000)

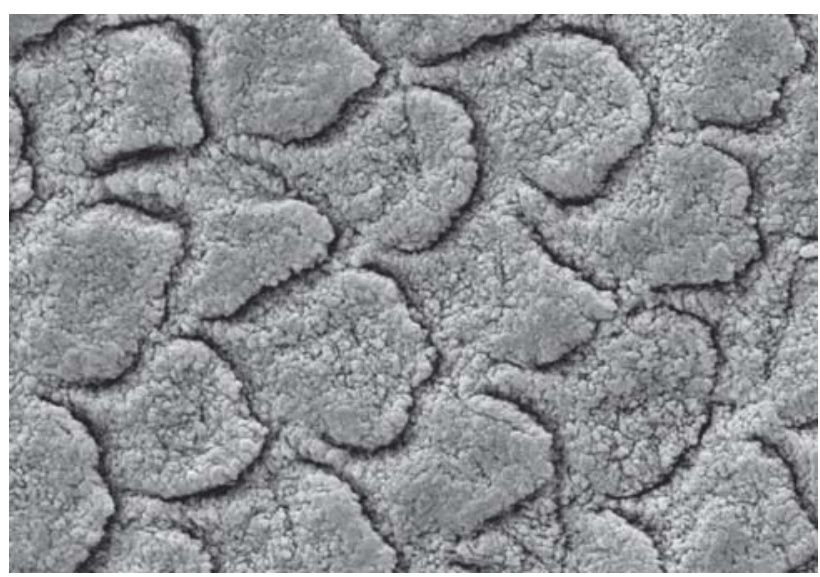

a

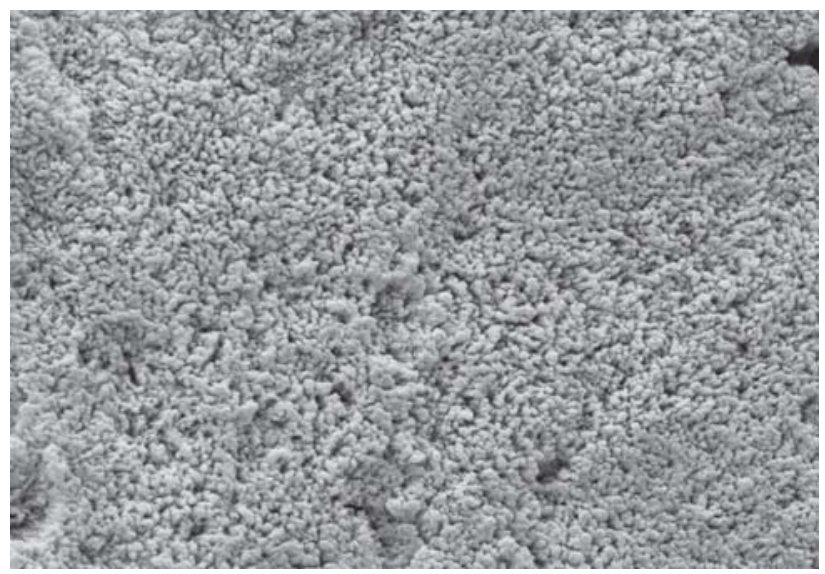

b

FIGURE 9- SEMs of ground (9a) and intact (9b) enamel surfaces treated with Tyrian SPE self-etching primer. Aggressive etching effect similar to phosphoric acid etching in grounded enamel surfaces (9a). The application to intact enamel exposed enamel crystallites along the surface $(9 b)(x 10,000)$ 


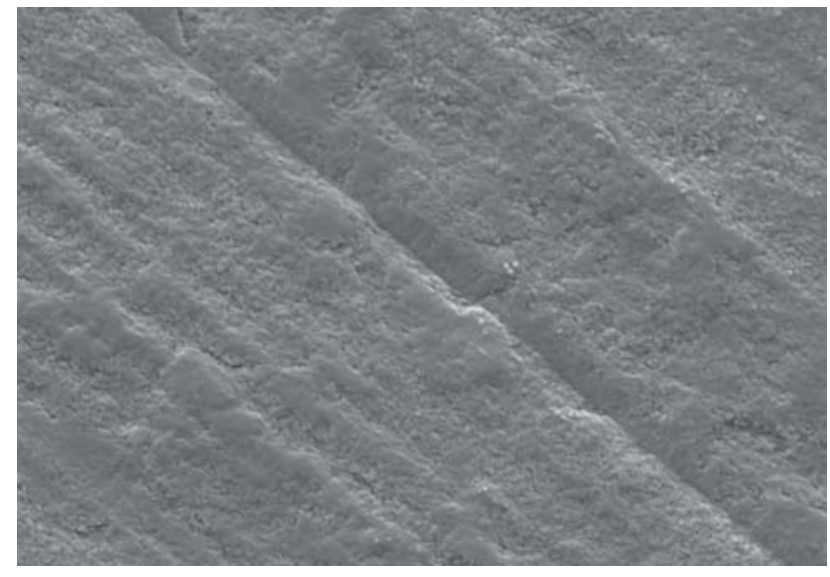

a

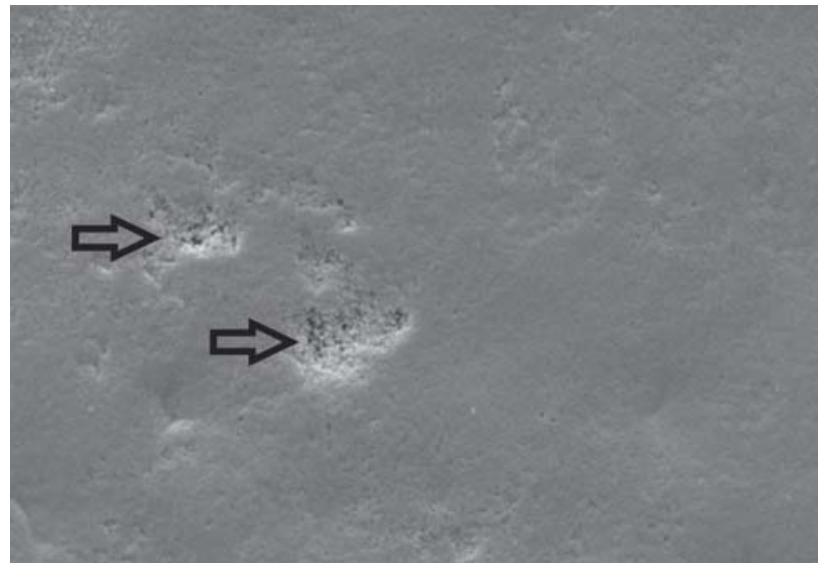

b

FIGURE 10- SEMs of ground (10a) and intact (10b) enamel surfaces treated with Unifil Bond self-etching primer. Mild etching effects were produced with shallow pits (arrows) in intact surfaces $(10 b)(\times 10,000)$

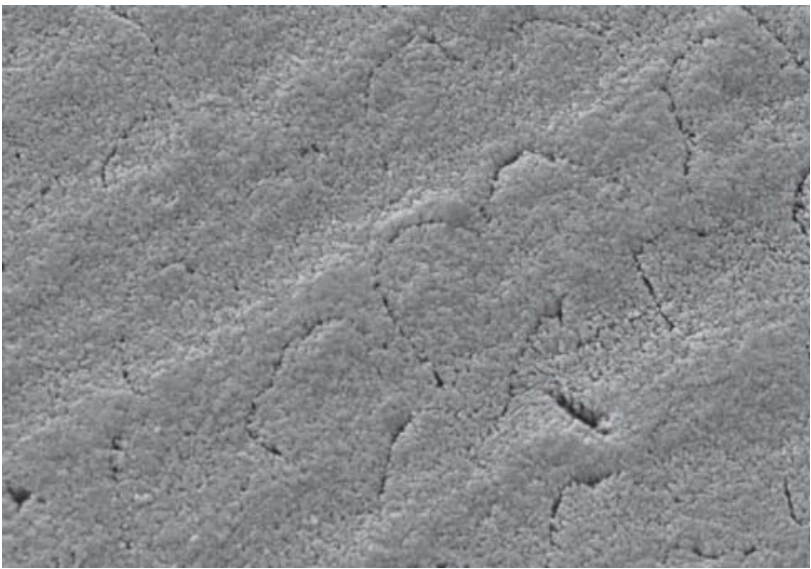

a

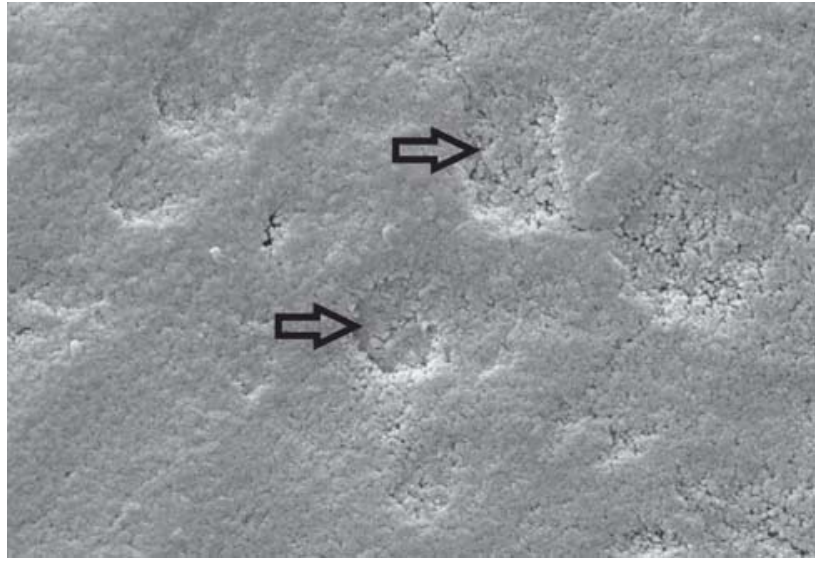

b

FIGURE 11- SEMs of ground (11a) and intact (11b) enamel surfaces treated with Xeno III self-etching adhesive. Enamel crystallites and interprismatic areas were observed after Xeno III application on ground surfaces (11a) and shallow pits (arrows) were noted along the intact surfaces $(11 \mathrm{~b})(\times 10,000)$

\section{REFERENCES}

1- Asmussen E, Peutzfeldt A. Short- and long-term bonding efficacy of a self-etching, one-step adhesive. J Adhes Dent. 2003;5:41-5.

2- Buonocore MG. A simple method of increasing the adhesion of acrylic filling materials to enamel surfaces. J Dent Res. 1955;34:84953.

3- Chaves P, Giannini M, Ambrosano GMB. Influence of smear pretreatments on bond strength. J Adhes Dent. 2002;4:191-6.

4- Clotte S, Blunck U, Roulet JF. The influence of a simplified application technique for ceramic inlays on the margin quality. J Adhes Dent. 1999;1:159-66.

5- Daronch M, De Goes MF, Grande RHM, Chan DCN. Antibacterial and conventional self-etching primer system: morphological evaluation of intact primary enamel. J Clin Pediatr Dent. 2003;27:251-6
6- Francescantonio M, Oliveira MT, Giannini M, De Goes MF. Evaluation of bond strength of adhesive systems to intact and ground enamel [abstract Ib111]. Braz Oral Res. 2004;80(Suppl):80.

7- Gordan VV, Vargas MA, Cobb DS, Denehy GE. Evaluation of adhesive systems using acidic monomer. Am J Dent. 1997;10:21923.

8- Hannig M, Reinhardt KJ, Bott B. Self-etching primer vs phosphoric acid: an alternative concept for composite-to-enamel bonding. Oper Dent. 1999;24:172-80.

9- Hannig M, Bock H, Bott B, Hoth-Hannig W. Inter-crystallite nanoretention of self-etching adhesives at enamel imaged by transmission electron microscopy. Eur J Oral Sci. 2002:110:464-70.

10- Hannig M, Grafe A, Atalay S, Bott B. Microleakage and SEM evaluation of fissure sealants placed by use of self-etching priming agents. J Dent. 2003;32:75-81.

11- Hashimoto M, Ohno H, Yoshida E, Hori M, Sano H, Kaga M, et al. Resin-enamel bonds made with self-etching primers on ground enamel. Eur J Oral Sci. 2003;111:447-53. 
12- Hayakawa T, Kikutake K, Nemoto K. Influence of self-etching primer treatment on the adhesion of resin composite to polished dentin and enamel. Dent Mater. 1998;14:99-105.

13- Kaaden C, Powers JM, Friedl KH, Schmalz G. Bond strength of self-etching adhesives to dental hard tissues. Clin Oral Investig. 2002;6:155-60.

14- Kanemura N, Sano H, Tagami J. Tensile bond strength to and SEM evaluation of ground and intact enamel surfaces. J Dent. 1999;27:523-30.

15- Miyazaki M, Sato M, Onose H. Durability of enamel bond strength of simplified bonding systems. Oper Dent. 2000;25:75-80.

16- Miyazaki M, Hinoura K, Honjo G, Onose H. Effect of selfetching primer application method on enamel bond strength. Am J Dent. 2002;15:412-6.

17- Miyazaki M, Sato H, Onose H, Moore BK, Platt JA. Analysis of the enamel/adhesive resin interface with laser Raman Microscopy. Oper Dent. 2003;28:136-42.

18- Pashley DH, Tay FR. Aggressiveness of contemporary selfetching adhesives Part II: etching effects on unground enamel. Dent Mater. 2001;17:430-44.

19- Perdigão J, Lambrechts P, Van Meerbeek B, Tome AR, Vanherle G, Lopes AB. Morphological field emission-SEM study of the effect of six phosphoric acid etching agents on human dentin. Dent Mater. 1996;12:262-71.

20- Perdigão J, Lopes L, Lambrechts P, Leitão J, Van Meerbeek B. Effects of a self etching primer on enamel shear bond strengths and SEM morphology. Am J Dent. 1997;10:141-6.

21- Perdigão J, Geraldeli S. Bonding characteristics of self-etching adhesives to intact versus prepared enamel. J Esthet Restor Dent. 2003; $15: 32-41$.

22- Poole DFG, Johnson NW. The effect of different demineralizing agent on enamel surface studies by scanning electron microscopy. Arch Oral Biol. 1967;12:1621-34.

23- Reis AF, Aguiar FHB, Pereira PNR, Giannini M. Enamel roughness and bond strength after phosphoric acid and/or self-etching primer application [abstract 3115]. J Dent Res. 2004(sp issue A):83.

24- Reis AF, Arrais CA, Novaes PD, Carvalho RM, De Goes MF, Giannini M. Ultramorphological analysis of resin-dentin interfaces produced with water-based single-step and two-step adhesives: nanoleakage expression. J Biomed Mater Res. 2004;71B:90-8.

25- Retief DH. Effect of conditioning the enamel surface with phosphoric acid. J Dent Res. 1973;52:333-41.

26- Shimada Y, Tagami J. Effects of regional enamel and prism orientation on resin bonding. Oper Dent. 2003;28:20-7.

27- Silverstone LM, Saxton CA, Dogon IL, Fejerskov O. Variation in the pattern of acid etching of human dental enamel examined by scanning electron microscopy. Caries Res. 1975;9:373-87.

28- Torii Y, Itou K, Nishitani Y, Ishikawa K, Suzuki K. Effect of phosphoric acid etching prior to self-etching primer application on adhesion of resin composite to enamel and dentin. Am J Dent. 2002;15:305-8

29- Torii Y, Itou K, Hikasa R, Iwata S, Nishitani Y. Enamel tensile bond strength and morphology of resin-enamel interface created by acid etching system with or without moisture and self-etching priming system. J Oral Rehabil. 2002;29:528-33.
30- Van Meerbeek B, De Munck J, Mattar D, Van Landuyt K, Lambrechts P. Microtensile bond strengths of an etch\&rinse and self-etch adhesive to enamel and dentin as a function of surface treatment. Oper Dent. 2003;28:647-60. 